\title{
The Greatest Man In the World. The life and ethics of Albert Schweitzer in the eyes of students pursuing medical and legal degrees
}

\author{
Marcin Cybulski ${ }^{1}$, Wojciech Strzelecki', Paweł Chmielowski ${ }^{2}$, Bogusław Stelcer ${ }^{1,3}$, \\ Bartosz Bilski ${ }^{4}$, Maria Grzymisławska-Cybulska ${ }^{5,6}$
}

${ }^{1}$ Department of Clinical Psychology, Poznan University of Medical Sciences, Poland

${ }^{2}$ Institute for Social and Market Research TriC, Poland

${ }^{3}$ Institute of Human Nutrition and Dietetics, Poznan University of Life Science, Poland

${ }^{4}$ Department of Preventive Medicine, Poznan University of Medical Sciences, Poland

${ }^{5}$ Provincial Administrative Court in Poznan, Poland

${ }^{6}$ The Law Institute, SWPS University of Social Sciences and Humanities, Poland

\begin{abstract}
Introduction. Albert Schweitzer (1875-1965) was an Alsatian doctor, philosopher-ethicist, theologist, lutheran pastor and musician-organ player and musicologist. In 1913 he started his medical practice in Lambaréné (Gabon) in which he built from scratch his greatest legacy - The Albert Schweitzer Hospital. Due to an involvement of doctors and nursing staff from all over the world this hospital has been functioning and developing to this day. In 1952 he was awarded the Nobel Peace Prize for his engagement into the promotion of peace, disarmament and the prevention of imperial arms race. Currently, his spiritual and scientific legacy constitutes an element of biophilic angle in academic curricula at all levels of education also in medical sciences mainly in the United States and Western Europe.

Material and Methods. The research is based on a questionnaire evaluating the level of awareness of Albert Schweitzer's person, his legacy and concepts. The survey was completed by 53 law students of the SWPS University of Social Sciences and Humanities in Poznan and 435 medical studies students of the University of Medical Sciences in Poznań. The respondents did the following various studies: medicine, dentistry, pharmacy, obstetrics, paramedicine, dietetics, optometry, physiotherapy and occupational therapy.

Results. Only 5.5\% (n27) of the students from both Universities know about Albert Schweitzer and his works. Albert Schweitzer is not perceived as a medical doctor, entrepreneur-philanthropist, lutheran pastor, political activist, musician, musicologist and the winner of the Nobel Peace Prize. Not many people have heard about the Reverence for Life (19\%, n93), however, they recognise Albert Schweitzer's connection to philosophy and ethics. Conclusions. Despite the Albert Schweitzer's presence in the Polish bioethical debate and his popularity in the 60 s to the 80 s, today he becomes obsolete. Even at the university level education in the areas of science in which morality and ethics provide basic professional principles - an unaided recall of his name and works among young people is rare.
\end{abstract}

Keywords: Albert Schweitzer, ethics, bioethics, medical education, legal education.

\section{Introduction}

Albert Schweitzer (1875-1965) was an Alsatian theologian and Lutheran pastor. Regardless his theological education, he was also interested in philosophy and music. He was awarded a doctorate in philosophy and later was qualified as an assistant professor in theology [a post doctorate degree awarded in many European countries] [1]. 
However, at the same time he was developing academically in the field of musicology. His research on the life and work of Johann Sebastian Bach (1908) is still one of the most complete sources of knowledge on the Bach's music [2]. Schweitzer was also a practicing musician (he learnt how to play organ under the watchful eyes of Eugène Munch and Charles-Marie Widor) [3]. His experience with philosophy, theology and musicology made him change the direction of personal development and at the beginning of the 20th century he began to study medicine and in the end he got a PhD qualification in this field. In 1913, in Lambaréné (Gabon, Africa), he and his wife, Helene Bresslau, founded a hospital for local communities [4]. The project was financed by private funds as well as public donations. The Albert Schweitzer Hospital still exists and is one of the better-equipped medical and research facilities in Africa which hosts specialists from all over the world - also doctors and nurses from Poland. Similar medical centres were created in Haiti and Mexico [5].

In the last period of his life Schweitzer took up music and philanthropy. Moreover, he worked on the principles of the reverence for life idea (veneratio vitae) which encapsulates respect for all forms of life and can be summed up by the quote "I am life that wills to live in the midst of life that wills to live" [6]. It stipulates that from recognising and understanding the will of life becomes an obligation to respect and cherish it. Sustaining and supporting life is good while destroying or harming it is bad. Among many well-known quotes there is a particular one which gained a lot of recognition Das Glück ist das einzige, was sich verdoppelt, wenn man es teilt. In 1952 Albert Schweitzer was awarded the Nobel Peace Prize for his engagement into promotion of peace, disarmament and the prevention of imperial arms race [7]. In his social and peace activities he cooperated with such famous people as: Albert Einstein and Bertrand Russell. Today, his work and ideas are still present in many countries' educational curricula - mainly in lutheran ones. There is also a wider following of the Schweitzer's ideas in the United States, Germany, Japan and France [8]. In the beginning of $21^{\text {st }}$ century Albert Schweitzer is a highly recognised personality not exclusively in the fields of medicine and science. In Poland it is prof. dr hab. n. med. Henryk Gaertner from Cracow who spreads the Schweitzer's ideas $[9,10]$. Another centre whose mission is to make those ideas popular is the Pol- ish Albert Schweitzer's Society in Poznan which is driven by the engagement of the scientists of the Poznan University of Medical Sciences [11].

\section{Material and Methods}

The research is based on our own survey, created just for the purpose of this study in which we assessed the awareness level of Albert Schweitzer, his work and ideas. The questionnaire included 5 questions. The participation in the study was anonymous and voluntary. The time for the questions was unlimited. The interviewees did not use any external sources of information. The survey was completed by 53 law students (out of the total of 160) at the SWPS University of Social Sciences and Humanities in Poznań, Poland and 435 students (out of the total of 4972) at the University of Medical Sciences in Poznań, Poland. The respondents did the following various studies: medicine (n69), dentistry (n76), pharmacy (n61), obstetrics (n63), paramedicine (n45), dietetics (n52), optometry (n21), physiotherapy (n23) and occupational therapy (n25). The respondents' average age was 21 and it ranged from 18-24. There were 358 women (73\%) and 130 men $(27 \%)$ in the researched group.

\section{Results}

They were first asked if they had ever heard about Albert Schweitzer. Only 5.5\% of the students from both Universities knew about Albert Schweitzer and his works. Among the younger respondents (under 21 year old, the median) fewer people knew about Albert Schweitzer (5.0\%) than in the older group (6.3\%), however those differences are not big nor statistically significant. Neither of the fields of studies seemed to have significant impact on their answers. Among the law and medicine students, $5.7 \%$ and $5.5 \%$ respectively, recognized the name of Albert Schweitzer.

Next, the study participants were asked who Albert Schweitzer was and to describe with different levels of probability (from 1 to 6 where 1 meant - the least probable and 6 - the most) whether he did any of the things listed in the questionnaire. The most participants claimed he was an ethicist and a philosopher (an average of 4.12 out of 6 ) and a doctor working in Gabon (an average of 3.21). The fewest people knew that he was a musician 
and musicologist (an average of 2.12). Not all the answers given in this questionnaire were correct as the researchers wanted to check the students' knowledge of the activities which Albert Schweitzer did not actually do. A detailed breakdown of the results is presented in Table $\mathbf{1}$.

One factor did not matter in perceiving Schweitzer's role - the respondents age. Among the answers who Schweitzer might have been there were no statistically significant discrepancies between the under 21 age group and the older one.

However, there were statistically significant differences relating to the University in which the respondents studied. Those differences were noticeable in the answers "pastor" (the average amounted to 2.30 for the law students while for the medicine students it was 2.76, $p=0.13$ $\mathrm{df}=486$ ) as well as for "doctor working in Gabon" (the average 2.62 for the law students and 3.28 for the medicine, $p=0.38 d f=486$ ). A detailed breakdown is presented in Table 2 .

Not many interviewers have heard about Schweitzer's Reverence for Life Ethics, only one respondent out of five (19.1\%). When considering the respondents' age, the awareness of Reverence for Life ethics was not statistically significant. In the younger group it was $16.4 \%$ and $23.3 \%$ of the in the older one. There were no significant differences regarding the respondents' field of study. Among the law students and the medicine students it was $22.6 \%$ and $18.6 \%$ respectively.

However, when describing what the Reverence for Life Ethics meant, the majority of the respondents gave correct answer - they said it had been a set of ethical values on the respect for life (average value of 4.48 out of 6 ). It is quite surprising that many respondents, a large part of them studying medicine, answered this question by marking that

Table 1. Who was Albert Schweitzer? (from 1 to 6 where 1 meant the least probable and 6 - the most)

\begin{tabular}{lc}
\hline Assess with some level of probability that Albert Schweitzer was: & Average \\
\hline Pastor & 2.71 \\
\hline Politician and social movements leader: & 2.73 \\
\hline Entrepreneur-philanthropist & 2.67 \\
\hline Albert Einstein's friends and Bertrand Russell's co-worker & 2.65 \\
\hline Doctor working in Gabon & 3.21 \\
\hline Ethicist and philosopher & 4.12 \\
\hline Church history researcher & 2.59 \\
\hline Musician and musicologist & 2.12 \\
\hline Nobel Peace Prize winner & 2.67 \\
\hline
\end{tabular}

Table 2. "Who was Albert Schweitzer?" - with regard to the respondents' field of study

\begin{tabular}{llccc}
\hline \multicolumn{1}{c}{ Albert Schweitzer was: } & Field of study & $\mathrm{N}$ & Average \\
\hline \multirow{2}{*}{ Pastor } & Law & 53 & $2.30^{\mathrm{a}}$ \\
\cline { 2 - 4 } Politician and social movements leader & Medicine & 435 & $2.76^{\mathrm{a}}$ \\
\hline \multirow{2}{*}{ Entrepreneur-philanthropist } & Law & 53 & 2.68 \\
\cline { 2 - 4 } & Medicine & 435 & 2.74 \\
\hline \multirow{2}{*}{ Albert Einstein's friend and Bertrand Russell's co-worker } & Law & 53 & 2.40 \\
\cline { 2 - 4 } & Medicine & 435 & 2.71 \\
\cline { 2 - 4 } & Medicine & 53 & 2.30 \\
\hline \multirow{2}{*}{ Doctor working in Gabon } & Law & 53 & 2.69 \\
\cline { 2 - 4 } & Medicine & 435 & $3.62^{\mathrm{b}}$ \\
\hline \multirow{2}{*}{ Ethicist and philosopher } & Law & 53 & 4.26 \\
\cline { 2 - 4 } & Medicine & 435 & 4.11 \\
\hline \multirow{2}{*}{ Church history researcher } & Law & 53 & 2.68 \\
\cline { 2 - 4 } & Medicine & 435 & 2.58 \\
\hline \multirow{2}{*}{ Musician and musicologist } & Law & 53 & 1.98 \\
\cline { 2 - 4 } & Medicine & 435 & 2.13 \\
\hline \multirow{2}{*}{ Nobel Peace Prize winner } & Law & 53 & 2.87 \\
\cline { 2 - 4 } & Medicine & 435 & 2.64 \\
\hline
\end{tabular}

$a-t$ student $p=0.13 d f=486 ; b-t$ student $p=0.38 d f=486$ 
it was a part of the Doctor's Oath, an element of the old Hippocratic Oath (3.55). A detailed breakdown of the answers distribution is shown in Table 3.

Regarding this question, the field of studies did not play statistically significant role. However, there were some major differences, connected with the respondents' age, in answers to two questions: one of the parts of the Doctor's Oath, an element of the old Hippocratic Oath (average of 3.68 for 21 and under, 3.34 for over 21 respondents, $p=0.12 \mathrm{df}=486$ ) and a set of ethical principles on the Respect for Life (average of 4.35 for 21 and under and 4.68 for over $21, p=0.02$ $\mathrm{df}=486$ ). A detailed breakdown of the answers distribution is shown in Table 4.
Albert Schweitzer, were ahead of their time by influencing the way of thinking and life of the people around them by means such as: word, activity and example. That is why we believe he is one of the greatest humanist of all times [11]".

The analysis of literature points out to the extraordinariness of Schweitzer, being the reason for his popularity - his works were translated into at least 20 languages [4], his ideas were adopted by curricula in many countries (e.g. Japan, Turkey or Korea) [10] whilst in research conducted in Europe in the 1950's, young people were asked who their ideal modern hero was and it was Albert Schweitzer who appeared to be the first. [4]. He is one of a few people with a wide moral recogni-

Table 3. What is the Reverence for Life Ethics? from 1 to 6 where 1 meant the least probable and 6 - the most)

\begin{tabular}{lc}
\hline \multicolumn{1}{|c}{ The Reverence for Life Ethics is: } & Average \\
\hline One of the part of the Doctor's Oath (an element of the old Hippocratic Oath) & 3.55 \\
\hline A book's title & 3.24 \\
\hline A set of ethical principles on the respect for life & 4.48 \\
\hline A set of lectures given by world peace activists (e.g. Bertrand Russell, Albert Einstein, Albert Schweitzer) & 3.14 \\
\hline
\end{tabular}

Table 4. "What is the Reverence for Life Ethics?" - taking into account the respondents' age.

\begin{tabular}{l|rrc}
\hline \multicolumn{1}{|c}{ The Reverence for Life Ethics is: } & Age median & N & Average \\
\hline \multirow{2}{*}{ One of the part of the Doctor's Oath (an element of the old Hippocratic Oath) } & $\leq 21$ & 298 & $3.68^{\text {a }}$ \\
\cline { 2 - 4 } & $>21$ & 190 & $3.34^{\text {a }}$ \\
\hline \multirow{2}{*}{ A book's title } & $\leq 21$ & 298 & 3.30 \\
\hline \multirow{2}{*}{ A set of ethical principles on the respect for life } & $>21$ & 190 & 3.16 \\
\hline A set of lectures given by world peace activists (e.g. Bertrand Russell, Albert & $\leq 21$ & 298 & $4.35^{\mathrm{a}}$ \\
\cline { 2 - 4 } \\
\cline { 2 - 4 } Einstein, Albert Schweitzer) & $>21$ & 190 & $4.68^{\mathrm{a}}$ \\
\hline
\end{tabular}

$a-t$ Student, $p=0.12 d f=486 ; b-t$ Student, $p=0.02 d f=486$

\section{Discussion}

The low level of knowledge of Albert Schweitzer among the researched students of those branches may seem quite surprising due to his presence in multiple domains of science and art. It was difficult to characterize, describe or somehow classify him. A wide variety of his activities slips away the one-dimensional pattern of thinking. It is not easy to get a complete knowledge of a person who was at the same time a musician, doctor, philosopher and theologist, and when needed, also an architect and carpenter. He was also described as a peace activist, caretaker and writer. Gerald Goetting in his foreword to the book about Albert Schweitzer Begegnungen mit Albert Schweitzer wrote: "There are not many people who, just like tion that in a two-piece book there were almost a 100 authors representing different continents, views and political ideas paying tribute to Albert Schweitzer $[4,12,13]$. However, it is a fact that the popularity of the doctor from Lambaréné and the interest in his person have decreased significantly. It is partly contributed to the fact that his values may seem too traditional for the young generation [4] as well as his language might not be communicative to the youth. It might be also owing to an anxiety, when meeting such an ethics role-model, caused by obvious comparisons.

One might assume that in Western Europe the awareness of this person is higher due to his presence in public life. In those countries there are many schools (excluding universities, colleges and institutes) which have Albert Schweitzer 
as their patron: in Germany - 19, France -7 , the Netherlands - 5, the USA - 3 [14]. The data is incomplete, however, even the above-mentioned numbers would cause a higher level of awareness of Albert Schweitzer. In Poland there is one school: Gimnazjum i Liceum Ogólnokształcące Ewangelickiego Towarzystwa Edukacyjnego im. Alberta Schweitzera [Albert Schweitzer Junior High and High Schools curated by the Lutheran Education Association] in Gliwice. Many research and academic institutions in the world use Albert Schweitzer's name and promote his works: the Albert Schweitzer Institute of Chapman University (California, the USA), the Albert Schweitzer Institute of Quinnipiac University (Connecticut, the USA), the Albert Schweitzer International University (Madrid, Spain) with its branches in Switzerland and Argentina and Association Internationale pour l'Oeuvre du Docteur Albert Schweitzer de Lambaréné (AISL) - widely known as the International Schweitzer Foundation.

The low awareness of Albert Schweitzer in Poland is mostly contributed to the history of the country and this person's life story. Henryk Gaertner, who contributed the most to spread Schweitzer's ideas in Poland, believes that "Poland's distance from Lambaréné, long-term and multiple socioeconomic difficulties of the post-war period in our country, and also Schweitzer's turbulent story, as well as (...) many obstacles in West-East relationships did not create good grounds (...) for free dissemination and deeper understanding of his ideas and works [in Poland] [10].

The question "Who was Albert Schweitzer", given in the questionnaire, was quite a challenge for the respondents as they were unlikely to be sure what type of activities were linked with this name. Even more, to give a correct answer, one would require references to many fields and domains he contributed to. On the one hand, it mmight be surprising but on the other, also researchers and scientists sometimes find it difficult, not to answer who he was, but rather to describe who he predominantly was. Alfons Skowronek refers to this discussion as follows: "Ten years ago, in 1975, in Warsaw an intradisciplinary symposium was organised to celebrate the 100th anniversary of Albert Schweitzer's birth. During the conference I had an opportunity to present my work on Albert Schweitzer as a theologist. I claimed that (...) he was in fact mainly a great theologist.
However, a lively discussion (...) informed me that Schweitzer was predominantly the greatest and most current social ethicist. Another participant to this discussion pointed out that he was (...) mainly an extraordinary peace activist. Some philosophers were proponents of the view that he was a philosopher and writer above all other qualities. Then a person dealing with medicine named Schweitzer an exemplary doctor with a true calling. Lastly, there was a musicologist who defended the opinion that for music passionates Schweitzer is only associated with studies of Bach and perfect organs' mastery" [15].

In today's world Schweitzer ideas seem to be very relevant and valuable not only in medicine, but also in philosophy. Zbigniew Filar believes that "it is a challenge to the medicine of our times, and as such so often accused of losing its great humanistic ideas and going towards the soulless technology" [10].

The humanity in our geopolitical situation needs Schweitzer's ideas. As his concern of the human race was expressed in his speeches on peace and the crisis of culture, rooted, according to Schweitzer, in thoughtless technological advancements [16]. He believed that those advancements should be accompanied by ethical development of humanity as the lack of it may cause the main ideas of humanism to perish. He was convinced that the renaissance of culture is only possible when a person is appreciated as a thinking being, functioning in society as a sensitive moral subject [17]. Among three areas of progress that he enumerated: development of knowledge, skills and spirit - the last one was considered to be the most important for him $[16,18]$. He was concerned about human race and wrote, referring to the spiritual and ethical state of modern societies: "On many occasions I had to conclude that the public opinion does not reject openly-expressed de-humanising ideas, but instead, it tolerates them and de-humanised policy of states and nations is applauded as effective" [3]. Those fears seem to be worryingly and dangerously relevant today. Progress, and the knowledge that comes along with it, detached from the ethical development is, according to Schweitzer, not useful in life and lacks deeper meaning [19].

Looking at Schweitzer's ideas from an anthropological angle, it may point us to some important issues: Firstly, they show well how a group of indi- 
vidual subjects comes together as a population defined by cultural features. Secondly, it helps to understand the purpose of his ideas and activities in light of the theory of culture. Thirdly, what seems to be the most important (in the context of the current multilayered crisis), it helps to understand the significance of culture's constructs for the future and sustainable growth of the modern societies. It is all possible mainly due to the consistency and universal applications of Schweitzer's ideas [20].

\section{Conclusions}

The awareness of Albert Schweitzer and his works in Poland, despite some educational effords, is very low also among the students doing various medical degree, who should be guided by his biophilic principles in their professional lives. The current situation is related to Poland's historical and religious and cultural backgrounds. Although the ideas of Albert Schweitzer are quite popular in the countries influenced strongly by the Lutheran religion, as well as they are present in curricula in schools and also in pop-culture, the Polish reality is different. Despite the first wave of recognition in the 60-80s, the memory of Schweitzer, his works and ideas is fading away. In 1947, The Life Magazine named Albert Schweitzer "the greatest man in the world" [21]. We can just hope that his greatness shall not be forgotten.

\section{Acknowledgements}

The authors would like to express their thanks to Professor for his inspiration and the promotion of Albert Schweitzer's ideas in Poland.

\section{Conflict of interest statement}

The authors declare no conflict of interest.

\section{Funding sources}

There are no sources of funding to declare.

\section{References}

1. Götting G. Spotkanie z Albertem Schweitzerem. Warszawa: Instytut Wydawniczy PAX; 1961.

2. Schweitzer A. Jan Sebastian Bach. Biografia. Warszawa: Wydawnictwo W.A.B.; 2009

3. Schweitzer A. Z mojego życia... Warszawa: Instytut Wydawniczy PAX; 1981.

4. Lazari-Pawłowska I. Myśli i ludzie. Schweitzer. Warszawa: Wiedza Powszechna; 1976.

5. Gaertner H, Stelcer B, Wissel E. Albert Schweitzer. Stulecie szpitala w Lambaréné (Gabon), Archiwum Historii i Filozofii Medycyny. 2013;76(1):46-50.
6. Schweitzer A. Out of my Life and Thought, Baltimore: Johns Hopkins University Press; 1998.

7. Cavendish R. Albert Schweitzer's Nobel Prize. October 30th, 1953. History Today. 2003;53(10):57.

8. Abrel R. The Educational Legacy of Albert Schweitzer. Leadership in our time. Vital Speeches of the Day. 1980;46(13):391-395.

9. Gaertner H. Albert Schweitzer. Nauka dla wszystkich. 1978;283:3-33.

10. Gaertner H. Albert Schweitzer. Życie, myśl i dzieło, Kraków: Wydawnictwo WAM; 2007.

11. Gotting G. Przedmowa. In: Schweitzer A. Życie, Warszawa: Instytut Wydawniczy PAX; 1974: 5-6.

12. Bähr HW. Albert Schweitzer, Sein Denken und sein Weg. Tübingen: J.C.B Mohr (Paul Siebeck); 1962.

13. Götting G. Albert Schweitzer, Beiträge zu Leben und Werk. Berlin: Berlin Union-Verlag; 1966.

14. Google search, phrases: "Albert Schweitzer School”, "Albert Schweitzer Ecole”, „Albert Schweitzer Schule”, date: 20.02.2017.

15. Skowronek A. Albert Schweitzer jako teolog. In: Albert Schweitzer. Życie i dzieło. Materiały z międzynarodowej sesji w Krakowie w dn. 21-26.10.1985, Warszawa: Ośrodek Chrześcijańskiej Myśli Społecznej AUGUSTINUM; 1986: 39-49.

16. Strzelecki W. Kryzys kultury według Alberta Schweitzera. In: Pawlak P, Strzelecki W, da Costa GJM, editors. Kultura-media-etyka. Media w perspektywie etycznej i kulturowej w kontekście rewolucji teleinformatycznej, Poznań: Poznańskie Towarzystwo Przyjaciół Nauk; 2013: 117-26.

17. Piątek Z. Etyka szacunku dla życia Alberta Schweitzera a ekofilozofia. Problemy ekorozwoju. 2008;3(2):51-61.

18. Schweitzer A. Życie, Warszawa: Instytut Wydawniczy PAX; 1974.

19. Łobocki M. Altruizm i wychowanie, Lublin: Wydawnictwo Marii Curie-Skłodowskiej; 2004.

20. Strzelecki W, Pawlak P. Albert Schweitzer - konteksty społeczno-kulturowe. In Stelcer B, Strzelecki W, editors. Humanizm w medycynie, Poznań: Wydawnictwo Naukowe UMP; 2017: 106-18.

21. Fuller JM. Albert Schweitzer (1875-1965): Organist, Theologian, Nobel Laureate. In: Cooper DKC, editor. Doctors of Another Calling. Physicians Who Are Known Bestin Fields Other than Medicine, Newark: University of Delaware Press; 2014: 275-84.

Acceptance for editing: 2018-03-12 Acceptance for publication: 2018-03-27

Correspondence address: Marcin Cybulski Department of Clinical Psychology Poznan University of Medical Sciences, Poland Collegium Stomatologicum 70 Bukowska St, 60-812 Poznan phone: +48 605227567 email: cybulski@ump.edu.pl 